\title{
Comparison of Proteins from Mycobacterium fortuitum, Mycobacterium nonchromogenicum and Mycobacterium terrae using Flat Bed Electrophoresis
}

\author{
By DIRK A. VANDEN BERGHE AND STEFAAN R. PATTYN \\ Laboratory of Microbiology, Faculty of Medicine, U.I.A., B-2610 Wilrijk, Belgium
}

(Received 3 October 1978)

\begin{abstract}
Polyacrylamide gel electrophoresis of bacterial lysates in a flat bed gives a linear relationship between $\ln \mathrm{mol}$. wt of the proteins and the square root of their migration distances, thereby allowing standardization of different electrophoresis runs and precise comparison between homologous bands. The results obtained with Mycobacterium fortuitum, M. terrae and $M$. nonchromogenicum strains were used in numerical analysis. Mycobacterium fortuitum and $M$. nonchromogenicum showed a greater internal similarity than $M$. terrae, while two strains of the latter clustered with $M$. nonchromogenicum. The method described allows the comparison of mycobacteria with different generation times and provides a large number of good characters for numerical taxonomy.
\end{abstract}

\section{INTRODUCTION}

Electrophoresis of bacterial proteins has been widely used as a taxonomic tool (Chang $e t$ al., 1962; Gottlieb \& Hepden, 1966; Bent, 1967; Hall et al., 1969; Shipton \& Fleischmann, 1969; Huisingh \& Durbin, 1967; King et al., 1969; Rouatt et al., 1970; Palmer \& Cameron, 1971; Kersters \& De Ley, 1975; Haas et al., 1974; Hudson \& Quan, 1975; Swings et al., 1976). Protein separation is influenced by factors such as gel concentration, temperature, $\mathrm{pH}$, extraction methods, duration of electrophoresis and by the physiological state of the bacteria. Protein patterns are difficult to quantify visually and $R_{F}$ values have been determined by comparison with standard proteins (Kersters \& De Ley, 1975; Rouatt et al., 1970). Even so, there are difficulties in identifying homologous proteins as small differences in gel concentration may influence $R_{F}$ values for the same proteins and disturbances in the electric field may be caused by non-migrating proteins and nucleic acids. Similarly, densitometer readings may be influenced by the concentrations of homologous proteins or by the intensity with which they fix the stain, while individual proteins, visible with the naked eye, are sometimes not detected in this way. Kersters \& De Ley (1975) and Swings et al. (1976) proposed a strictly standardized method for the preparation of bacterial lysates and for electrophoresis, but the need for a visual compensation for homologous proteins remained and the method cannot be applied to organisms with widely different generation times and whose homologous proteins are present in various concentrations. Direct comparison of homologous protein bands can, however, be made by flat bed electrophoresis. In the present study a procedure for internal standardization was developed allowing the mathematical treatment of the data and comparison between different electrophoretic runs. 


\section{METHODS}

Organisms and culture conditions. Mycobacteria examined in previous taxonomic studies were used: Mycobacterium fortuitum strains 4, 81, 800, 516, 927, 928, 931, 630, 5, 33, 1812, 1954 (Pattyn et al., 1974); M. terrae ATCC 19531, 19619, 25113, 25146, 25147, 25149, 25268, 25217; M. nonchromogenicum ATCC 19530, 25142, 25143, 25144, 25266, 25219, 25145, 25218 (Meissner et al., 1974). The Escherichia coli strain was a clinical isolate.

The test strains were transferred from Lowenstein-Jensen slants to $100 \mathrm{ml}$ of $7 \mathrm{H} 10$ broth (Difco) containing $0.5 \%(\mathrm{w} / \mathrm{v})$ bovine albumin and incubated at $37^{\circ} \mathrm{C}$ for several days. These bacteria were then added to 11 flasks containing similar medium and incubated in a $37^{\circ} \mathrm{C}$ water bath with constant stirring. Cultures were plated on 7H10 agar to test for purity. Mycobacterium fortuitum strains produced maximum growth within 2 to $3 \mathrm{~d}, M$. terrae and $M$. nonchromogenicum after 7 to $10 \mathrm{~d}$.

Preparation of bacterial extracts. Cultures were centrifuged at $3000 \mathrm{~g}$ for $60 \mathrm{~min}$; the sediment was resuspended in $35 \mathrm{ml}$ Tris/ $\mathrm{HCl}$ buffer $(0.01 \mathrm{M}, \mathrm{pH} 7 \cdot 2)$ and rinsed three times with similar buffer. The dry weight was measured and the final suspension was made in $4 \mathrm{ml} 12.5 \mathrm{~mm}$-Tris $/ 120$ mM-glycine buffer pH 8.4. Bacteria were broken by 10 strokes of an X-press at $-25^{\circ} \mathrm{C}$. The final product was centrifuged at $10000 \mathrm{~g}$ at $4{ }^{\circ} \mathrm{C}$ for $20 \mathrm{~min}$; the supernatant was decanted and recentrifuged as before and then stored at $-20^{\circ} \mathrm{C}$. Protein was determined by the method of Lowry et al. (1951).

Polyacrylamide gel electrophoresis. Polyacrylamide gel $(8 \%, \mathrm{w} / \mathrm{v})$ was prepared as follows: $15 \cdot 36 \mathrm{ml}$ of a solution containing $50 \%(\mathrm{w} / \mathrm{v})$ acrylamide (Serva, Heidelberg, Germany) and $1.45 \%(\mathrm{w} / \mathrm{v}) N, N^{\prime}$-methylenebisacrylamide (Serva) were mixed with $12 \mathrm{ml}$ of a solution containing $0.4 \%(\mathrm{v} / \mathrm{v}) N, N, N^{\prime}, N^{\prime}$-tetramethyl-

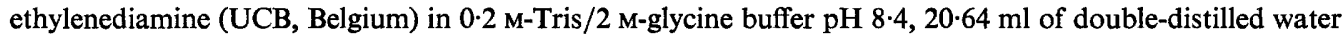
and $48 \mathrm{ml}$ of $0.3 \%(\mathrm{w} / \mathrm{v})$ ammonium persulphate. The mixture, prewarmed at $37^{\circ} \mathrm{C}$ for $15 \mathrm{~min}$, was placed between two glass plates $(20 \times 20 \mathrm{~cm}), 3 \mathrm{~mm}$ apart. Polymerization, under a layer of 1-butanol, was completed after $45 \mathrm{~min}$. The butanol was removed and a second gel (one-third of the volume of the $8 \%$ gel), with a concentration of $3.5 \%$ acrylamide in Tris/glycine buffer $\mathrm{pH} 8.4$ diluted $1 / 10$, was added. A comb with nine edentations was then introduced into the upper gel between the glass plates and 1-butanol was gently poured on to the surface of the gel through holes in the comb. Polymerization occurred within $2 \mathrm{~h}$. This technique has the advantage that proteins are situated on a straight line thereby allowing precise measurements of migration distances. After removing the comb the gel contained nine sample wells of $0.4 \mathrm{ml}$ capacity. Relatively large volumes of sample could be run without loss of resolution. The electrophoresis buffer was $25 \mathrm{~mm}$-Tris/ $240 \mathrm{~mm}$-glycine buffer $\mathrm{pH} 8.4$. A pre-run was done for $20 \mathrm{~min}$ at $50 \mathrm{~V}$ and, after removing the 1-butanol, bacterial lysates were introduced. The lysates contained $400 \mu \mathrm{g}$ protein in $250 \mu \mathrm{l}$ Tris/glycine buffer pH 8.4 with $12 \%(\mathrm{w} / \mathrm{v})$ sucrose. Bovine serum albumin (BSA) and bromothymolblue were sometimes added in separate wells. Electrophoresis was carried out at $50 \mathrm{~V}$ for $16 \mathrm{~h}$. Staining was done in $0.25 \%$ $(\mathrm{w} / \mathrm{v})$ Coomassie brilliant blue (R $25 \mathrm{G}$, Gurr) in $45 \%(\mathrm{v} / \mathrm{v})$ methanol and $9.4 \%(\mathrm{v} / \mathrm{v})$ acetic acid, and destaining with $45 \%(\mathrm{v} / \mathrm{v})$ methanol and $10 \%(\mathrm{v} / \mathrm{v})$ acetic acid. Gels were stored at $4{ }^{\circ} \mathrm{C}$ in $7 \%(\mathrm{v} / \mathrm{v})$ acetic acid.

\section{RESULTS AND DISCUSSION}

\section{Flat bed electrophoresis}

The protein patterns of 12 strains of $M$. fortuitum revealed only small variations in the total number of proteins for each strain in different runs, although, as illustrated in Fig. 1, important differences in the concentrations of some homologous proteins could be observed for different bacteria. Comparable results were obtained for samples between 0.3 and $0.05 \mathrm{ml}$.

$R_{F}$ values, measured as the migration distance in the main gel of a protein fraction relative to the migration distance for the standard protein (BSA), were constant for the different runs. The means of the $R_{F}$ values (distance meniscus BSA/distance meniscus protein) for protein X of strain 928 and for protein $\mathrm{Y}$ of strain 516 (see Fig. 1) obtained in 12 different runs were, respectively, $2.19(\sigma=0.04)$ and $1.70(\sigma=0.06)$.

\section{Comparison between strains}

Five electrophoretic runs of two separate culture batches for each of three strains of $M$. fortuitum (strains $928,516,927$ ) were compared by scoring 1 for a protein band each time it was present. In practice most bands had a score of 5 with only very faint bands having 
(a)

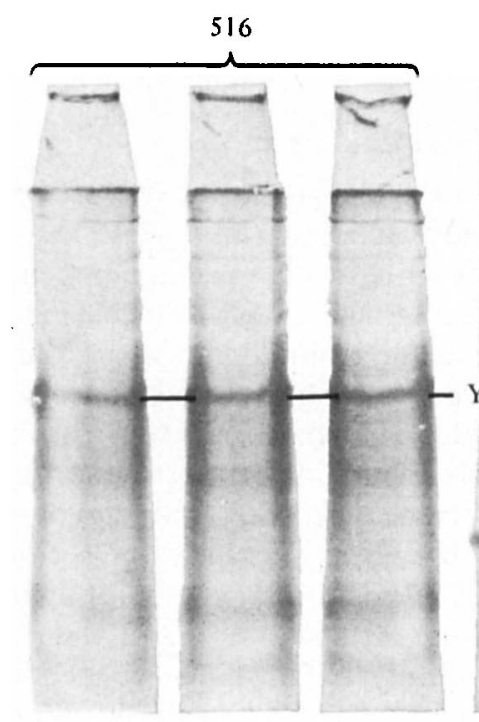

BSA
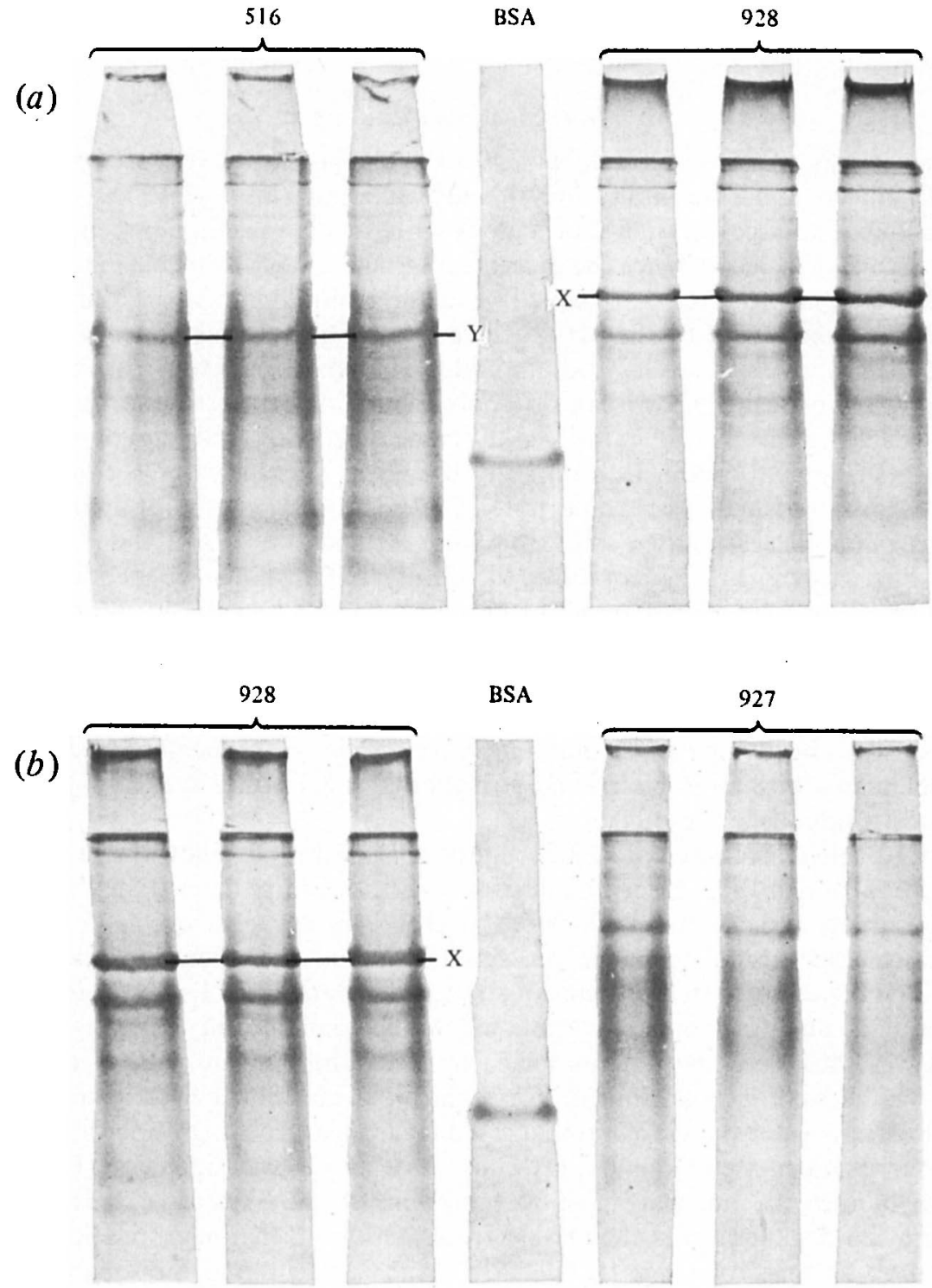

BSA

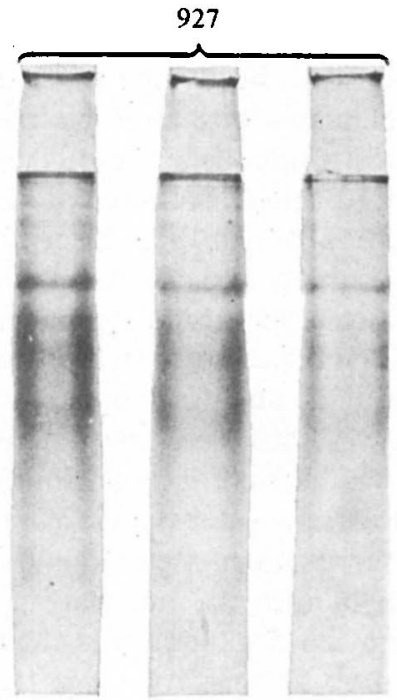

Fig. 1. Flat bed polyacrylamide gel electrophoresis of bacterial extracts from three different cultivations of $M$. fortuitum strains (a) 516 and 928 and $(b) 927$ and 928 , together with bovine serum albumin (BSA). Protein band X of strain 928 and band $Y$ of strain 516 are indicated.

lower scores. Between them, the three strains exhibited 39 individual protein bands and at least 18 of the bands were present in all strains. Strains 516 and 927 are similar since each of the 39 protein bands was either present in both strains or absent. Similarity coefficients were calculated from the results, but these only take into account the protein bands present in the organisms investigated. The procedure therefore does not allow comparisons with bacteria which produce protein bands with other $R_{F}$ values. This difficulty could be solved by dividing the gel into identical 'units' of, for example, $1 \mathrm{~mm}$ and scoring each unit as positive or negative for the presence or absence of a protein band. However, such a procedure is applicable only when the electrophoresis is absolutely standardized, that is the migration distance of a marker protein, for example BSA, should always be the same and differences in gel concentrations should be non-existent. These difficulties are solved by the 
introduction of an internal standardization, eliminating the effects of small differences in gel concentration, voltage and electrophoresis time.

\section{Internal standardization}

Electrophoresis of ferritin (mol. wt 540000), catalase (mol. wt 240000), BSA (mol. wt 67000) and its dimer (mol. wt 134000) and ovalbumin (mol. wt 45000) in five separate runs at different voltages showed that there is a linear relationship between $\ln$ mol. wt and the square root of $r$, the distance the proteins migrated in the main gel (Fig. 2). Ovalbumin at $\mathrm{pH} 8.4$ always produced two equally intense bands $3 \mathrm{~mm}$ apart, but their relative intensities were influenced by the $\mathrm{pH}$ at which electrophoresis was done. When ovalbumin was examined in a gel containing sodium dodecyl sulphate, only one band appeared. Thus we interpret the presence of two bands in polyacrylamide gel electrophoresis of ovalbumin at $\mathrm{pH} 8.4$ as being due to configurational differences between molecules of ovalbumin. The slower migrating band cannot be a dimer of the faster migrating one because the distance between them is too small. For the purpose of calculation, a point midway between the two bands of ovalbumin was chosen as its migration distance.

Small differences in $\mathrm{pH}$ did not affect the linear relationship since identical results were obtained on electrophoresis of standard proteins at $\mathrm{pH} 8$ and $\mathrm{pH} \mathrm{9}$; the time of electrophoresis was also unimportant (Fig. 3). The most important factor in the system was glycine: when electrophoresis was done in Tris buffer without glycine at identical $\mathrm{pH}$, the linearity was lost. It is possible that glycine plays a similar role to sodium dodecyl sulphate in other systems, by giving the proteins a negative charge. This was illustrated by the finding that $\beta$-lactamases with an isoelectric point higher than 8.4 in this system migrated towards the cathode (unpublished results).

Bacterial proteins followed the same linear relationship, as shown in a more detailed study of $M$. fortuitum 1812 . Electrophoresis was performed five times (Fig. $4 a$ ) with separate bacterial extracts and reference proteins. For each run, the relationship $\ln$ mol. wt versus $r^{\frac{1}{2}}$ was calculated for the reference proteins (Fig. $4 b$ ). The migration distances of four prominent and well-separated proteins of strain 1812, designated I, II, III and IV (Fig. 4a), were measured and their apparent mol. wts were calculated on the basis of the results obtained with the standard proteins for each electrophoretic run. The mean mol. wts of proteins I to IV were then calculated. For each of two additional electrophoretic runs with extracts of strain 1812, the points obtained from the measured migration distances and the mean mol. wts calculated from the previous runs lay on a straight line (Fig. $4 c$ ). Using these straight lines, the mol. wts of two other proteins (A and B) were derived after measuring their migration distances. In a further electrophoretic run, the linear relationship between In mean mol. wt for proteins I, II, III and IV and A and B and the square root of their migration distances was confirmed (Fig. $4 d$ ).

The results show that for bacterial proteins there is a linear relationship between $\ln$ mol. wt and $r^{\frac{1}{2}}$. An internal standardization is thus introduced independently of the migration distance, at least for proteins of mol. wt between 20000 and 1200000 . Proteins of higher mol. wt do not penetrate into the gel, while proteins of lower mol. wt either run out of the gel or their bands become too broad in the lower part of the gel, due to diffusion, to permit precise measurements.

\section{Comparison of bacterial proteins for taxonomic purposes}

An ideal gel is imagined and divided into numbered $1 \mathrm{~mm}$ 'gel units' starting from the top. In this gel, a protein with a mol. wt of 1200000 is situated $0.1 \mathrm{~cm}$ from the top, while one with a mol. wt of 22000 is situated at $11.0 \mathrm{~cm}$. The straight line of the internal standardization in this gel runs through these two points (Fig. $5 a$ ). Each gel unit, of which there are 120 per electrophoretogram, represents a definite value of mol. wt and each protein occupies 


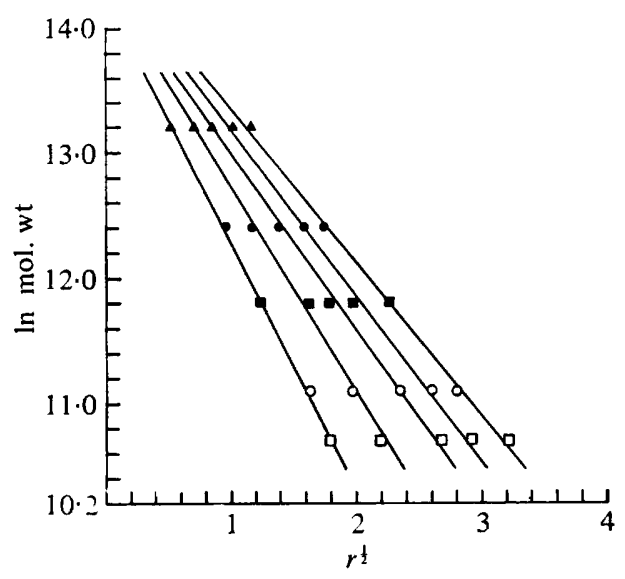

Fig. 2

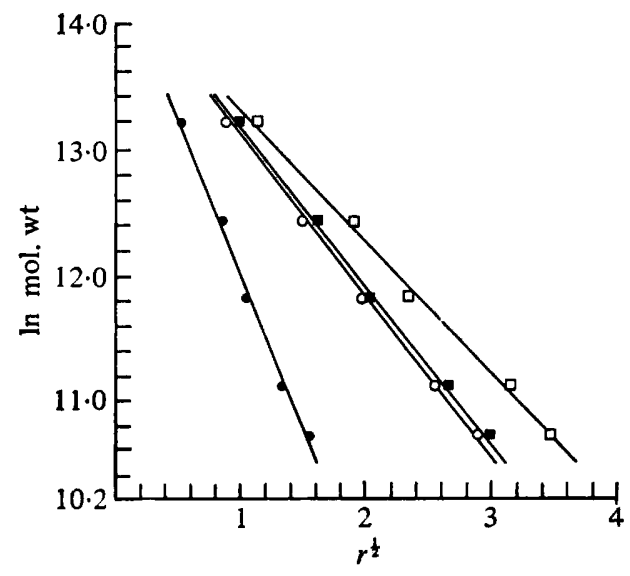

Fig. 3

Fig. 2. Relationship between the migration distance, $r$, and the molecular weight of the standard proteins ferritin $(\boldsymbol{\Delta})$, catalase $(\boldsymbol{O})$, BSA dimer $(\boldsymbol{\square})$, BSA $(O)$ and ovalbumin $(\square)$ for five separate electrophoretic runs at different voltages (from left to right 50,70, 90, 110 and $120 \mathrm{~V}$ ).

Fig. 3. Relationship between the migration distance, $r$, and the molecular weight of the standard proteins for four separate electrophoretic runs at $75 \mathrm{~V}$ under different conditions: $0,7 \mathrm{~h}$ run at $\mathrm{pH}$ $8 \cdot 4 ; \bigcirc, 14 \mathrm{~h}$ run at $\mathrm{pH} 8 \cdot 0 ; \mathbf{v}, 14 \mathrm{~h}$ run at $\mathrm{pH} 9 \cdot 0 ; \square, 18 \mathrm{~h}$ run at $\mathrm{pH} 8.4$.
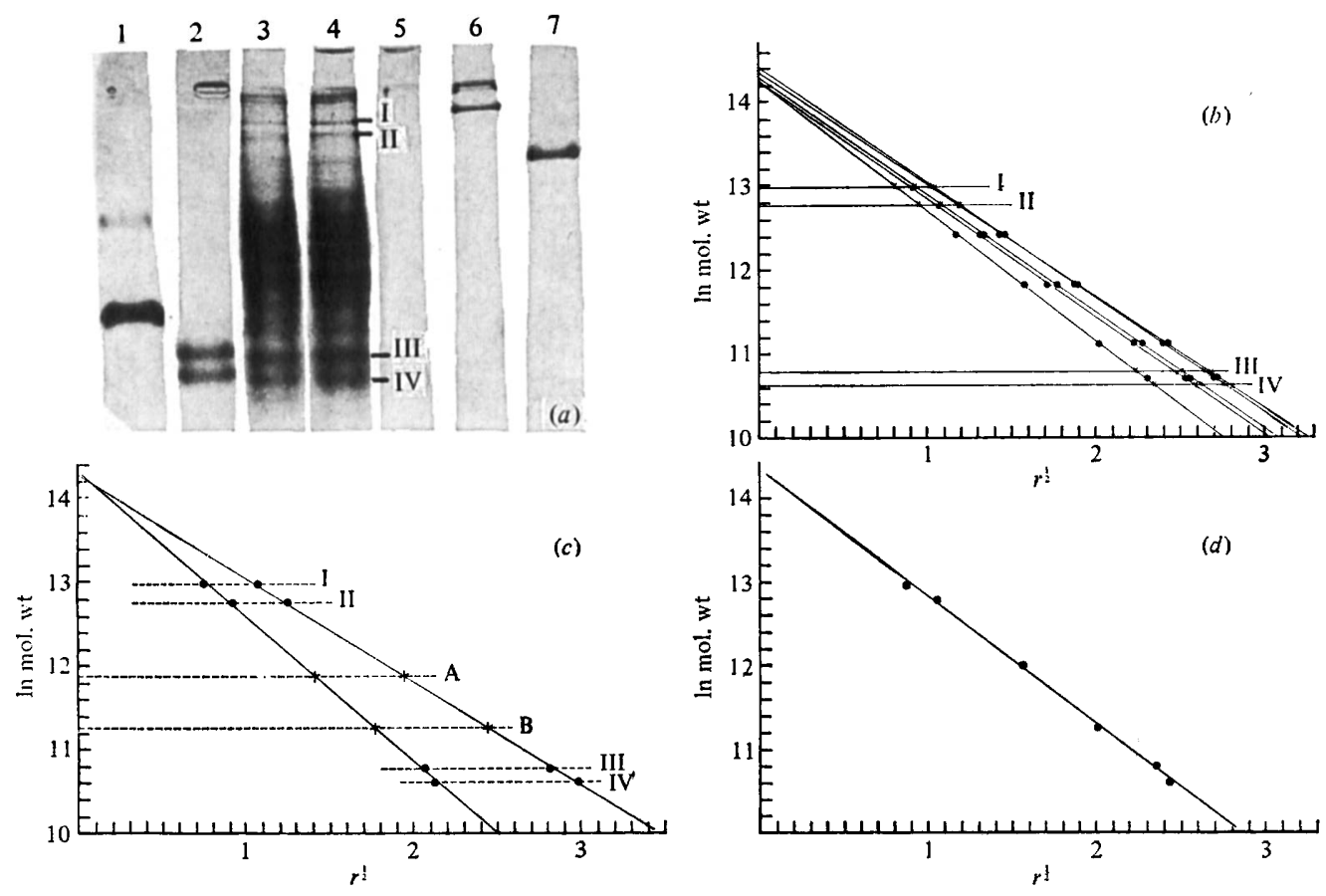

Fig. 4. (a) Flat bed electrophoresis of $M$. fortuitum 1812 extract ( 3 and 4) and the standard proteins [BSA and dimer (1), ovalbumin (2), ferritin (6), catalase (7)]. Four well-separated bacterial proteins (I, II, III and IV) are indicated.

(b) Five different electrophoretic runs of $M$. fortuitum 1812 extract in the presence of reference proteins were examined. For each run, the relationship between mol. wt and $r$ was determined for the standard proteins, and the mol. wts of proteins I, II, III and IV (a) were calculated on the basis of the linear relationship of the reference proteins. The mean values of these molecular weights are indicated.

(c) Two electrophoretic runs of $M$. fortuitum 1812 extract were examined: plots of ln mol. wt versus $r^{\frac{1}{2}}$ for the bacterial proteins I, II, III and IV $(a)$ gave straight lines. The mol. wts of two other bacterial proteins (A and B) were calculated for each run using these lines.

(d) A further electrophoretic run of $M$. fortuitum 1812 extract, confirming the linear relationship between $\ln$ mol. wt and $r^{\frac{1}{2}}$ for proteins I, II, III, IV, A and B. 
such a unit; for example, BSA, mol. wt 67000, occupies unit number 62 (Fig. $5 a$ ). After electrophoresis of a bacterial extract with appropriate standards, the mol. wt of each protein can be calculated and entered in the corresponding unit (Fig. $5 b$ ). The bacterial protein pattern can be coded using 120 numbers representing the units on the ideal gel.

Five electrophoretograms were examined and each unit was scored from 0 to 5 depending on the frequency of detection of protein bands in that unit. If two bands were observed in one unit, the protein band with the lowest mol. wt was designated A and the other B. This procedure, therefore, allowed the absence of protein bands in a unit to be taken into account. The method applied to $M$. fortuitum 1812 gave the following results: $1: 0 ; 2: 5 ; 3: 0 ; 4: 5$; $5: 5 ; 6 \mathrm{~A}: 5 ; 6 \mathrm{~B}: 5 ; 7: 0$ etc. (see Table 1 ).

\section{Application of standardized flat bed electrophoresis to lysates of $M$. fortuitum, $M$. nonchromogenicum and $M$. terrat}

Lysates of the test strains, prepared from at least two different culture batches, were subjected to electrophoresis using strain 1812 as the reference strain for internal standardization. An identical code number was given to homologous bands followed by the frequency of detection in five different electrophoretic runs. For non-homologous bands the mol. wt was determined on the straight line obtained for strain 1812 allowing the attribution of a code number when this mol. wt value was transferred to the ideal straight line. The results obtained for 12 strains are shown in Table 1.

\section{Numerical analysis}

Similarity coefficients were calculated from the electrophoresis results using the equation $S=(1-D) \times 100$, where $D$ is the distance between two strains; it represents the sum of the absolute values of the differences of the encoded values divided by the maximum number of possible differences, in this case $5 \times 80=400$ (Boeyé \& Aerts, 1976). Dendrograms and similarity matrices were derived from these data by the unweighted pair group method using arithmetic averages (Sneath \& Sokal, 1973) with the aid of the program Cluswec developed by P. Van Hecke and L. Bamps, University of Antwerp, Belgium.

Protein electrophoresis of the $M$. fortuitum strains showed that they shared a similarity level of $75 \%$ (Fig. 6a), with the three previously recognized subspecies (Pattyn et al., 1974) clustering at the levels of $95 \%$ (biotype B), $86 \%$ (biotype A) and $95 \%$ (biotype C) with strains 800 and 1954 linking them. The $M$. nonchromogenicum strains shared a high internal similarity of $94.5 \%$ with the exception of strain 25142 which clustered at $81 \%$ (Fig. $6 a$ ). The $M$. terrae strains had a lower internal similarity of $71 \%$ and three subgroups were recognized (Fig. $6 a$ ). When $M$. nonchromogenicum and $M$. terrae strains were compared, three clusters were distinguished: a cluster containing the highly similar $M$. nonchromogenicum strains with two $M$. terrae strains, and two clusters composed only of $M$. terrae strains.

When the results for all the test strains were compared (Fig. $6 b$ ), the $M$. fortuitum subclusters were interspersed between the $M$. terrae and $M$. nonchromogenicum groups showing that on the basis of protein electrophoresis these taxa have a higher degree of similarity than is indicated on the basis of 'classical' tests.

The protein electrophoresis technique developed in this study was applied to the welldefined rapidly growing species, $M$. fortuitum (Kubica et al., 1972), and to two slowly growing species, $M$. nonchromogenicum and $M$. terrae, which are much less clearly separated (Meissner et al., 1974). Kubica et al. (1972) found that the taxon $M$. fortuitum had an internal similarity of $80 \%$ and could be divided into two subclusters showing internal similarities of 90 and $85 \%$, respectively. In a later investigation (Pattyn et al., 1974), three $M$. fortuitum biotypes were recognized on the basis of a few characters. These three biotypes were also recovered in the present study. The strains classified as $M$. nonchromogenicum on the basis 


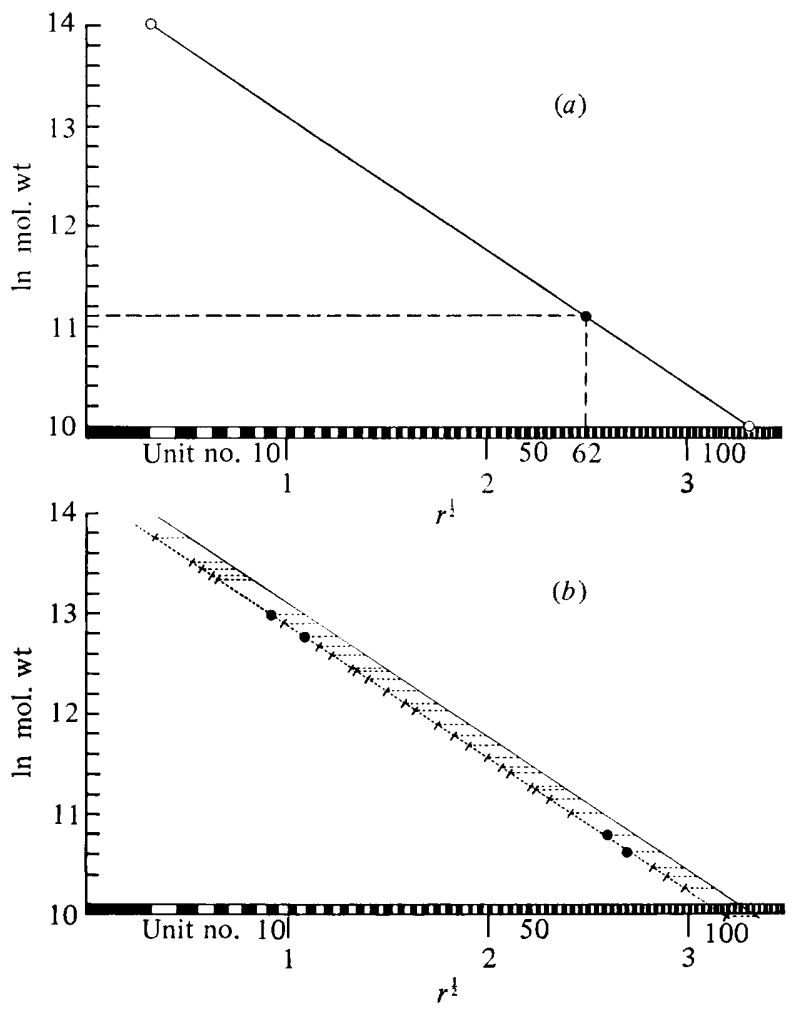

Fig. 5. (a) Representation of an ideal gel divided into numbered $1 \mathrm{~mm}$ units. Protein mol. wt 1200000 is situated at $0.1 \mathrm{~cm}$ from the top $(\bigcirc)$ while protein mol. wt 22000 is situated at $11.0 \mathrm{~cm}$ from the top $(O)$. The straight line connecting these two reference points represents the internal standardization of the gel. In this gel, BSA (, mol. wt 67000$)$ occupies gel unit 62 .

(b) Electrophoresis of $M$. fortuitum 1812 extract. The linear relationship between $\mathrm{ln}$ mol. wt and $r$ for the bacterial reference proteins (see Fig. 4d) is shown (--- ), together with the straight line of internal standardization $(-)$, as in $(a)$. Each visible bacterial protein is indicated $(/)$ and extrapolation is made to the internal reference line on the basis of mol. wt. The corresponding unit for each bacterial protein can then be read.

Table 1. Frequency of detection of homologous proteins for strains of M. fortuitum, $M$. terrae and $M$. nonchromogenicum

Results are shown for the first 20 ideal gel units of five electrophoretograms; there are 120 such units in each gel.

Strain no.

\begin{tabular}{cccccccccccccc} 
Unit no. & \multicolumn{1}{c}{} & 5 & $\mathbf{3 3}$ & $\mathbf{1 8 1 2}$ & 19619 & 19531 & 25219 & 25218 & 25266 & 25144 & 25145 & 25143 & 19530 \\
$1 \mathrm{~A}$ & 0 & 0 & 0 & 0 & 0 & 4 & 5 & 3 & 5 & 5 & 5 & 4 \\
1 B & 0 & 0 & 0 & 5 & 4 & 1 & 1 & 0 & 0 & 0 & 0 & 0 \\
2 & 5 & 5 & 5 & 3 & 5 & 5 & 5 & 5 & 5 & 5 & 5 & 5 \\
3 & 0 & 0 & 0 & 0 & 0 & 0 & 0 & 0 & 0 & 0 & 0 & 0 \\
4 & 5 & 5 & 5 & 4 & 4 & 5 & 5 & 5 & 5 & 2 & 0 & 2 \\
5 & 5 & 5 & 5 & 4 & 4 & 5 & 5 & 5 & 5 & 5 & 5 & 5 \\
6 A & 5 & 5 & 5 & 2 & 4 & 5 & 5 & 5 & 5 & 5 & 5 & 4 \\
6 B & 5 & 5 & 5 & 5 & 5 & 3 & 3 & 5 & 5 & 0 & 0 & 5 \\
7 & 0 & 0 & 0 & 0 & 0 & 0 & 0 & 0 & 0 & 0 & 0 & 0 \\
8 & 0 & 0 & 0 & 0 & 0 & 0 & 0 & 0 & 0 & 0 & 0 & 0 \\
9 & 0 & 0 & 0 & 0 & 0 & 2 & 1 & 0 & 2 & 0 & 0 & 1 \\
10 & 0 & 0 & 0 & 0 & 0 & 0 & 0 & 0 & 0 & 0 & 0 & 0 \\
11 & 5 & 5 & 5 & 5 & 5 & 5 & 5 & 5 & 5 & 5 & 5 & 5 \\
12 & 0 & 0 & 0 & 0 & 0 & 0 & 0 & 0 & 0 & 0 & 0 & 0 \\
13 & 5 & 5 & 5 & 5 & 5 & 5 & 5 & 5 & 5 & 5 & 5 & 5 \\
14 & 0 & 0 & 0 & 0 & 0 & 0 & 0 & 0 & 0 & 0 & 0 & 0 \\
15 & 5 & 5 & 5 & 4 & 5 & 4 & 3 & 5 & 5 & 4 & 5 & 3 \\
16 & 0 & 0 & 0 & 1 & 0 & 0 & 0 & 0 & 0 & 0 & 0 & 0 \\
17 & 5 & 5 & 5 & 0 & 0 & 0 & 0 & 0 & 0 & 0 & 0 & 2 \\
18 & 0 & 0 & 0 & 0 & 0 & 0 & 0 & 0 & 0 & 0 & 0 & 0 \\
19 & 5 & 5 & 5 & 5 & 5 & 5 & 5 & 5 & 5 & 5 & 5 & 5 \\
20 & 0 & 0 & 0 & 0 & 0 & 0 & 0 & 0 & 0 & 0 & 0 & 0
\end{tabular}



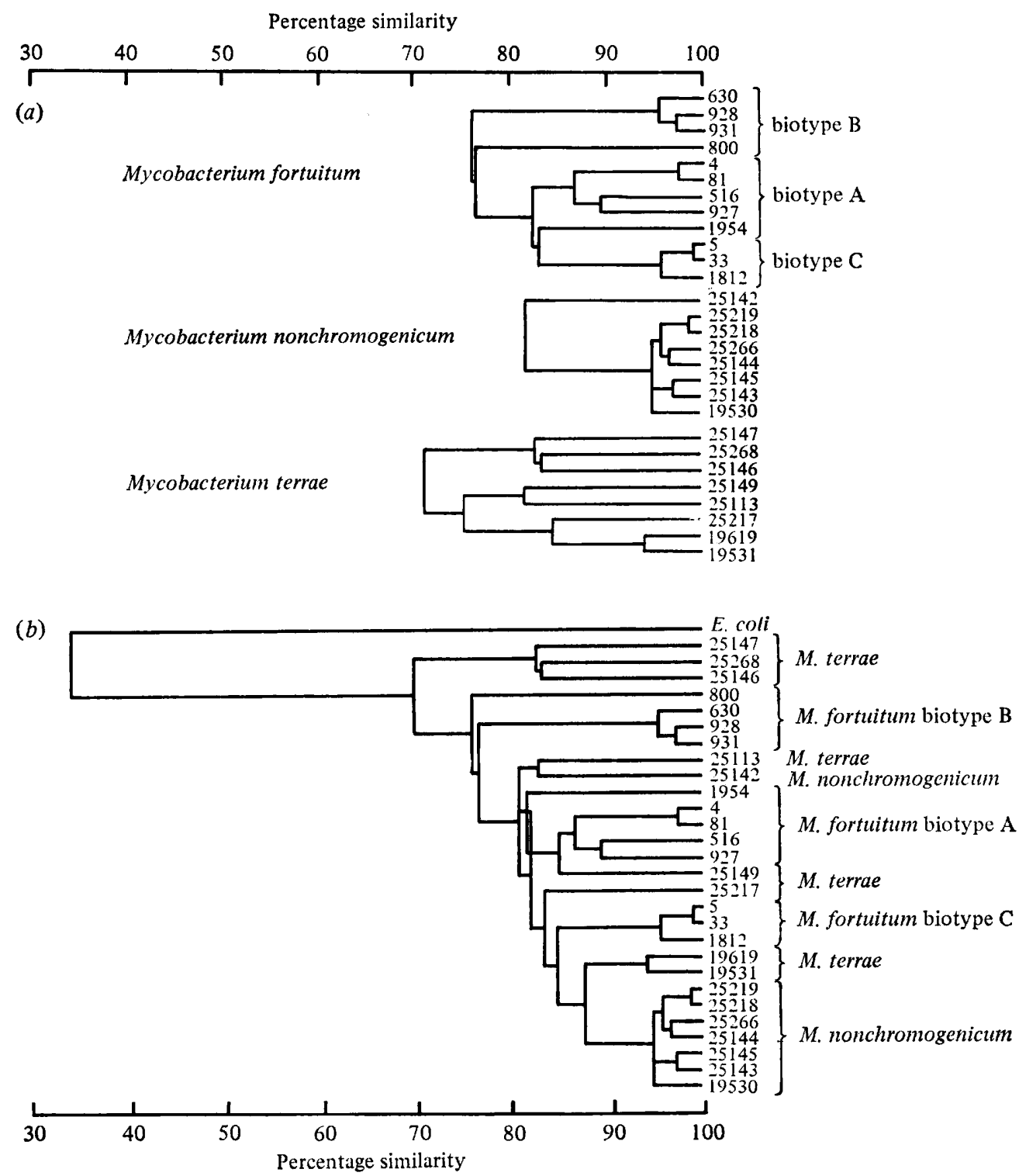

Fig. 6. (a) Dendrogram showing the relationships based on the electrophoresis of proteins from Mycobacterium fortuitum, $M$. terrae and $M$. nonchromogenicum. (b) Dendrogram based on the combined data from the three Mycobacterium species and an E. coli strain.

of numerical phenetic analysis were found, in the protein electrophoresis analyses, to be more homogeneous, except for one strain (ATCC 25142), whereas M. terrae strains were less homogeneous. Protein electrophoresis analysis supports the separation of these two species although two $M$. terrae strains clustered with $M$. nonchromogenicum. However, such overlapping has been detected previously (Meissner et al., 1974).

It seems, therefore, that classification based on the protein electrophoresis data is in good agreement with that obtained using other phenetic characters. All previous numerical taxonomic studies on mycobacteria (Wayne et al., 1971; Kubica et al., 1972; Meissner et al., 1974; Saito et al., 1977) were done separately either on rapidly or slowly growing 
strains, because many tests are applicable to only one of these two groups. Protein electrophoresis is applicable to both groups and shows that some rapidly growing mycobacteria are more closely related to some slowly growing taxa, for example $M$. fortuitum biotype $\mathrm{C}$ and $M$. nonchromogenicum, than has been suspected.

The number of characters useful for the comparison of strains with widely different generation times can be greatly extended by the application of the technique of protein electrophoresis.

Support by an FOP-UIA grant from the University of Antwerp is acknowledged together with the technical assistance of D. Haazen.

\section{REFERENCES}

BENT, K. J. (1967). Electrophoresis of proteins of 3 Penicillium species on acrylamide gels. Journal of General Microbiology 49, 195-200.

Boeyé, A. \& Aerts, M. (1976). Numerical taxonomy of Bacillus isolates from North Sea sediments. International Journal of Systematic Bacteriology 26, 427-441.

Chang, L. O., SrB, A. M. \& Steward, F. C. (1962). Electrophoretic separations of the soluble proteins of Neurospora. Nature, London 193, 756-759.

Gottlieb, D. \& Hepden, P. M. (1966). The electrophoretic movement of proteins from various Streptomyces species as a taxonomic criterion. Journal of General Microbiology 44, 95-104.

HaAs, H., Michel, J. \& SACKS, T. (1974). Identification of Mycobacterium fortuitum, Mycobacterium abscessus and Mycobacterium borstelense by polyacrylamide gel electrophoresis of their cell proteins. International Journal of Systematic Bacteriology 24, 366-369.

Hall, R., Zentmeyer, G. A. \& Erwin, C. D. (1969). Approach to taxonomy of Phytophthora through acrylamide gel-electrophoresis of proteins. Phytopathology 59, 770-774.

Hudson, B. W. \& QuAN, T. J. (1975). Electrophoretic studies of the yersiniae. American Journal of Tropical Medicine and Hygiene 26, 968-973.

Huisingh, D. \& Durbin, R. D. (1967). Physical and physiological methods for differentiating among Agrobacterium rhizogenes, A. tumefaciens and A. radiobacter. Phytopathology 75, 922-923.

Kersters, K. \& De Ley, J. (1975). Identification and grouping of bacteria by numerical analyisis of their electrophoretic protein patterns. Journal of General Microbiology 87, 333-342.

King, J. R., Theodore, T. S. \& Cole, R. M. (1969). Generic identification of L-forms by polyacrylamide gel-electrophoretic comparison of extracts from parent strains and their derived L-forms. Journal of Bacteriology 100, 71-77.

KubicA, G. P. \& 11 Others (1972). A co-operative numerical analysis of rapidly growing myco- bacteria. Journal of General Microbiology 73, 55-70.

Lowry, O. H., Rosebrough, N. J., FARr, A. L. \& Randall, R. J. (1951). Protein measurement with the Folin phenol reagent. Journal of Biological Chemistry 193, 265-175.

Meissner, G. \& 21 Others (1974). A co-operative numerical analysis of nonscoto- and nonphotochromogenic slowly growing mycobacteria. Journal of General Microbiology 83, 207-235.

Palmer, C. B. \& Cameron, H. R. (1971). Comparison of plant pathogenic pseudomonads by disc-gel electrophoresis. Phytopathology 61, 984986.

Pattyn, S. R., Magnusson, M., Stanford, J. L. \& Grange, J. M. (1974). A study of Mycobacterium fortuitum (tanae). Journal of Medical Microbiology 7, 67-76.

Rouatt, J. W., Skyring, G. W., Purkayastha, V. \& QUADLING, C. (1970). Soil bacteria: numerical analysis of electrophoretic protein patterns developed in acrylamide gels. Canadian Journal of Microbiology 16, 202-205.

Saito, H. \& 12 Others (1977). Co-operative numerical analysis of rapidly growing mycobacteria. The second report. International Journal of Systematic Bacteriology 27, 75-85.

Shipton, W. A. \& FleischmanN, G. (1969). Taxonomic significance of protein patterns of rust species and formae by disc electrophoresis. Canadian Journal of Botany 47, 1351-1358.

SNeath, P. H. A. \& Sokal, R. R. (1973). Numerical Taxonomy, pp. 230-234. San Francisco: W. H. Freeman.

Swings, J., Kersters, K. \& De Ley, J. (1976). Numerical analysis of electrophoretic protein patterns of Zymomonas strains. Journal of General Microbiology 93, 266-271.

Wayne, L. G. \& 14 Others (1971). A co-operative numerical analysis of scotochromogenic slowly growing mycobacteria. Journal of General Microbiology 66, 255-271. 